\title{
Pengaruh Pemberian Sediaan Emulgel Ekstrak Daun Kersen (Muntingia Calabura L.) Dan Emulgel Ekstrak Umbi Kentang (Solanum Tuberosum L.) Dengan Kitosan Sebagai Gelling Agent Terhadap Penyembuhan Luka Bakar Pada Kelinci
}

\author{
Brillyanti Monica Dita Anggraini ${ }^{1}$ Dan Herliyani ${ }^{2}$ \\ ${ }^{12}$ STIKes Borneo Cendekia Medika Pangkalan Bun \\ ${ }^{1}$ Email : brillyantimonica@yahoo.co.id
}

\begin{abstract}
ABSTRAK
Tanaman kersen (Muntingia calabura L.) banyak tumbuh secara liar diantara semak-semak belukar. Daun kersen mengandung flavonoid, tanin, dan saponin yang berpotensi sebagai pengobatan luka bakar. Bahan alam yang dapat digunakan salah satunya adalah kentang untuk kasus luka bakar. Kentang mengandung senyawa yang memiliki aktivitas antioksidan yaitu vitamin $\mathrm{C}$ dan flavonoid sebagai antibakteri. Adakah terdapat pengaruh pemberian sediaan emulgel ekstrak daun kersen (Muntingia calabura L.) dan sediaan emulgel ekstrak umbi kentang (solanum tuberosum l.) dengan kitosan sebagai gelling agent terhadap penyembuhan luka bakar pada kelinci. Jenis penelitian yang digunakan dalam penelitian ini adalah experimental murni dengan rancangan pre-posttest control group design. Hasil analisis data didapat dengan mengamati pengecilan diameter luka bakar menggunakan uji ANOVA. Sediaan emulgel-kitosan ekstrak kentang dan Sediaan emulgel ekstrak daun kersen (Muntingia calabura L.) dengan kitosan sebagai gelling agent efektif dalam proses penyembuhan luka bakar.
\end{abstract}

Kata Kunci : tanaman kersen, penyembuhan luka bakar

\section{Effect of Giving Emulgel Preparation of Kersen Leaf Extract (Muntingia calabura L.) and Potato Bulbs Emulgel Extract (Solanum tuberosum L.) with Chitosan as a Gelling Agent for Healing Burns in Rabbits}

\begin{abstract}
Cherry plants (Muntingia calabura L.) often grow wild among shrubs. Cherry leaves contain flavonoids, tannins, and saponins that have the potential as a treatment for burns. One of the natural ingredients that can be used is potatoes for burns. Potatoes contain compounds that have antioxidant activity, namely vitamin $C$ and flavonoids as antibacterial. Is there any effect on the administration of cherry leaf extract (Muntingia calabura L.) emulgel and potato tuber (solanum tuberosum L.) emulgel preparation with chitosan as a gelling agent for healing burns in rabbits. This type of research used in this study is purely experimental with a preposttest control group design. The results of data analysis were obtained by observing the reduction in burn diameter using the ANOVA test. Potato emulgelchitosan preparations and Cherry leaf extract (Muntingia calabura L.) emulgel with chitosan as an effective gelling agent in the process of healing burns
\end{abstract}


Keywords: cherry plant, burn healing

\section{PENDAHULUAN}

Kulit merupakan organ yang essensial dan vital serta merupakan cermin kesehatan dan kehidupan. Kulit juga sangat kompleks, elastis dan peka. Penyakit kulit yang sering dijumpai yaitu disebabkan oleh jamur, virus, bakteri, reaksi alergi, dan dapat juga karena benda panas yang menyebabkan terjadinya luka bakar (Handayani et al., 2015).

Penanganan pada penyembuhan luka bakar dapat dilakukan dengan cara mencegah infeksi sekunder, memacu pembentukan jaringan kolagen dan mengupayakan agar sisa-sisa sel epitel dapat berkembang sehingga dapat menutup permukaan luka. Proses penyembuhan pada luka bakar dibagi dalam tiga fase, yaitu fase inflamasi, proliferasi dan maturasi (Nazir et al., 2015).

Sediaan farmasi yang sering digunakan untuk formulasi obat luka bakar ada berbagai macam bentuk sediaan topikal, salah satunya emulgel. Sediaan topikal dalam bentuk emulgel dipilih karena mengandung fase minyak yang menyebabkan emulgel lebih unggul dari sediaan lain, sehingga obat akan melekat cukup lama dikulit, memiliki daya sebar yang baik, mudah dioleskan serta memberikan rasa nyaman pada kulit (Sari et al., 2015). Emulgel juga terdapat fase minyak yang berfungsi sebagai emolien atau occlusive yang akan mencegah penguapan sehingga kandungan air di dalam kulit dapat dipertahankan, oleh karena itu adanya sistem emulsi dalam bentuk sediaan emulgel akan memberikan penetrasi tinggi dikulit sehingga diharapkan dapat membantu mempercepat proses penyembuhan luka (Yenti et al., 2014).

Sediaan emulgel diperlukan penambahan gelling agent untuk mendapatkan stabilitas sistem yang baik. Pemilihan gelling agent sangat menentukan hasil akhir sediaan, salah satunya yang memiliki golongan polimer alam adalah kitosan. Kitosan adalah biopolimer alami yang berasal dari kitin, komponen utama dari kultikula (lobster, udang, kepiting). Beberapa penelitian menyatakan kitosan efektif dalam mempercepat penyembuhan luka karena mempunyai sifat spesifik yaitu adanya sifat bioaktif, biokompatibel, anti bakteri, anti jamur dan dapat terbiodegradasi (Putri dan Tasminatun, 2012).

Tanaman kersen (Muntingia calabura L.) banyak tumbuh secara liar diantara semak-semak belukar. Mudahnya tanaman kersen untuk tumbuh menyebabkan tanaman ini menjadi tumbuhan yang kadang tidak mempunyai nilai di masyarakat, padahal tanaman kersen merupakan salah satu tumbuhan yang menghasilkan suatu senyawa organik. Kandungan senyawa organik tanaman kersen terdapat pada kulit batang, buah hingga daun. Bagian dari tanaman kersen yang paling banyak kandungannya terdapat pada bagian daun. Daun kersen mengandung flavonoid, tanin, dan saponin yang berpotensi sebagai pengobatan luka bakar. Pada penelitian Handayani dan Sentat (2016) ekstrak etanol daun kersen dalam sediaan salep dosis 10,4 mg paling efektif terhadap penyembuhan luka bakar dengan persentase kesembuhan 93,3\% dan sebagai pengobatan analgetik dan antiinflamasi.

$$
\text { Bahan alam yang dapat }
$$


digunakan salah satunya adalah kentang untuk kasus luka bakar. Kentang mengandung senyawa yang memiliki aktivitas antioksidan yaitu vitamin $\mathrm{C}$ dan flavonoid sebagai antibakteri . Antioksidan seperti vitamin $\mathrm{C}$ merupakan senyawa yang dapat memproduksi kolagen pada tubuh jadi sangat berperan aktif menjaga kekencangan kulit dan didalam proses penyembuhan luka bakar dibutuhkan senyawa yang dapat pembentukan kolagen dengan cara memicu proliferasi sehingga terdapat peningkatan jumlah fibroblas. Peningkatan jumlah fibroblas akan mempercepat penyembuhan luka bakar dengan cara mengurangi ukuran luka yaitu tepitepi luka akan tertarik sehingga menutupi daerah yang terluka (Napanggala, 2014; Hayyu, 2013). Flavonoid sebagai antibakteri dengan cara merusak dinding sel bakteri (Istiana S, 2016). Pada penelitian Inkanesia Novaritasari (2014) perasan umbi kentang dalam sediaan gel dengan konsentrasi 2\%, 4\%,8 \% dimana konsentrasi $8 \%$ paling efektif mampu mempercepat penyembuhan luka bakar.

Berdasarkan uraian diatas maka akan dilakukan penelitian tentang pengaruh pemberian sediaan emulgel ekstrak daun kersen (muntingia calabura l.) dan emulgel ekstrak umbi kentang (solanum tuberosum l.) dengan kitosan sebagai gelling agent terhadap penyembuhan luka bakar pada kelinci.

\section{METODE PENELITIAN}

Jenis penelitian yang digunakan dalam penelitian ini adalah experimental murni (true experimental) dengan rancangan pre- posttest control group design. Teknik pengambilan sampel kentang dilakukan dengan cara simple random sampling. Hewan uji digunakan sebanyak 8 ekor kelinci. Setiap hewan uji di berikan perlakuan pemberian sediaan (konsentrasi 10\%, 20\%), kelompok kontrol negatif dan kelompok kontrol positif (Bioplacenton). Sampel pada penelitian ini adalah tanaman kersen dan kentang yang ada di kotawaringin barat. Hasil analisis data didapat dengan mengamati pengecilan diameter luka bakar menggunakan uji ANOVA.

\section{Hasil dan Pembahasan}

Penelitian ini bertujuan untuk mengetahui tentang pengaruh pemberian sediaan emulgel ekstrak daun kersen (Muntiniga calabura L.) dan sediaan emulgel ekstrak kentang dengan kitosan sebagai gelling agent terhadap penyembuhan luka bakar pada kelinci. Penelitian ini mengamati ada atau tidaknya efek dari bahan tersebut untuk penyembuhan luka bakar.

\section{Hasil uji efektivitas ekstrak daun kersen (Muntingia calabura L.) luka bakar pada kelinci}

Hasil efektivitas penyembuhan luka bakar pada kelinci yang diberi sediaan emulgel ekstrak daun kersen (Muntingia calabura L.) dengan kitosan sebagai gelling agant diuji berdasarkan luka bakar pada punggung kelinci yang dibuat 4 luka dengan menggunakan logam panas, masing-masing luka diberi perlakuan yang berbeda yaitu kontrol positif $(\mathrm{K}+)$ yang digunakan adalah Bioplacenton®, emulgel tanpa ekstrak sebagai kontrol negatif (K-), emulgel ekstrak daun kersen (Muntingia calabura L.) $10 \%$ dengan kitosan 
sebagai gelling agent (F1), dan emulgel ekstrak daun kersen (Muntingia calabura L.) 20\% dengan kitosan sebagai gelling agent (F2), sebelum dibuat luka hewan uji diadaptasikan 7 hari dengan tujuan menurut penelitian Ramdaniah (2014) agar hewan uji mampu menyesuaikan diri dalam kondisi lingkungan yang baru sebelum pengujian dimulai. Hewan uji disimpan pada kandang yang berbeda. Masing-masing hewan uji dicukur pada daerah punggung, hal ini bertujuan untuk membuat luka bakar dan memudahkan dalam

Tabel 5.5. Rata-rata persentase penyembuhan luka bakar

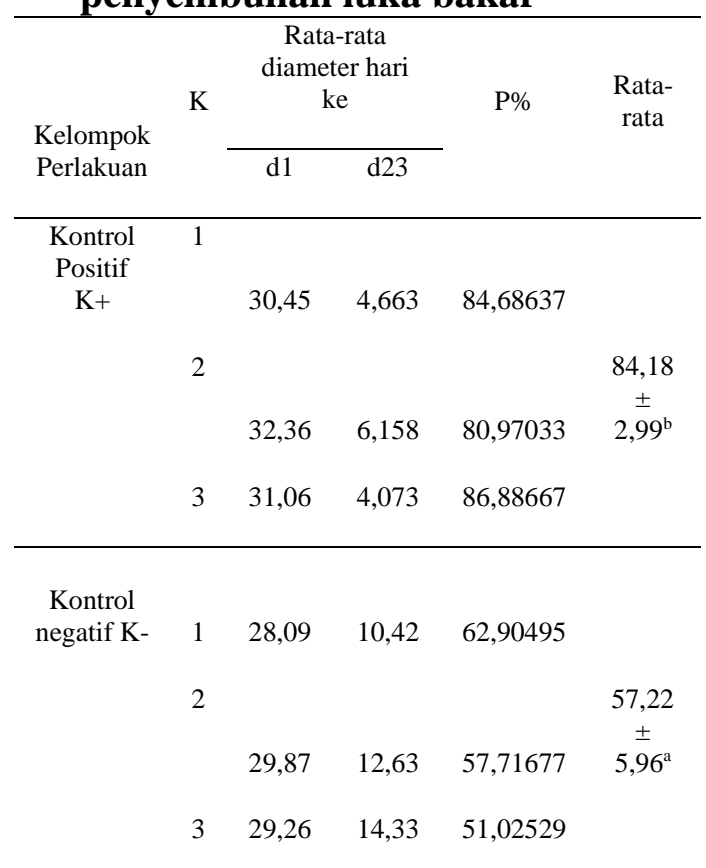

pengamatan luka bakar dari hari kehari setelah perlakuan dilakukan.

Hasil uji efektivitas luka bakar pada kelinci dapat dilihat rata-rata persentase penurunan diameter luka bakar untuk setiap kelompok perlakuan yaitu kelompok perlakuan $\mathrm{K}+\quad$ (Bioplacenton $\left.{ }^{\circledR}\right), \quad$ kelompok perlakuan K- (emulgel tanpa ekstrak), kelompok perlakuan F1 (Emulgel ekstrak daun kersen (Muntingia calabura L.) konsentrasi 10\%), dan kelompok perlakuan F2 (Emulgel ekstrak daun kersen (Muntingia calabura L.) konsentrasi 20\%) dapat dilihat pada gambar 5.1.

$\begin{array}{llll}3 & 30,41 & 4,863 & 84,00855\end{array}$

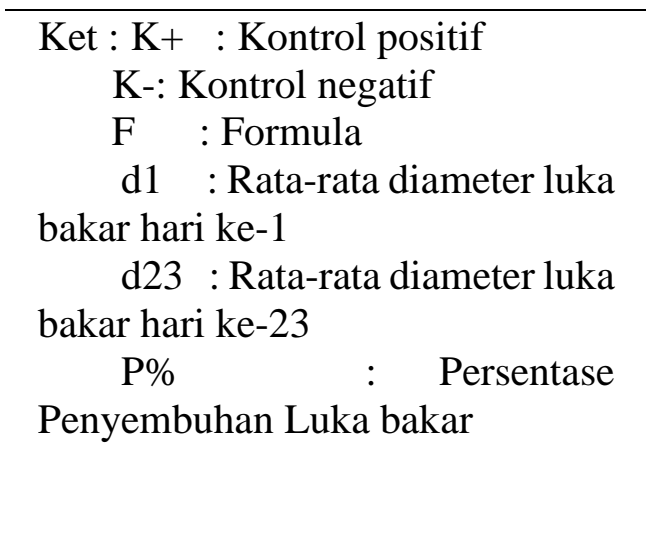
Hasil pengujian Efektivitas Sediaan Emulgel Kitosan-Ekstrak Kentang
Tabel Persen Penyembuhan LukaBakar

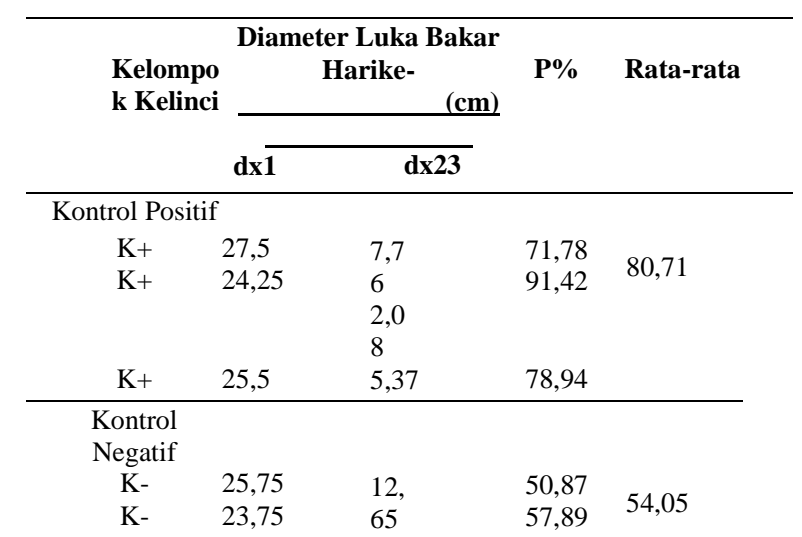




\begin{tabular}{|c|c|c|c|c|}
\hline \multicolumn{5}{|c|}{10} \\
\hline K- & 18,5 & 8,62 & 53,40 & \multirow{5}{*}{69,15} \\
\hline \multicolumn{5}{|c|}{ Emulgel } \\
\hline F3 & 17,5 & 6,1 & 64,85 & \\
\hline \multirow[t]{2}{*}{ F3 } & 26 & 5 & $\begin{array}{l}04,0 J \\
75,11\end{array}$ & \\
\hline & & & & \\
\hline F3 & 21,92 & 7,12 & 67,51 & \\
\hline \multirow{2}{*}{\multicolumn{5}{|c|}{ Emulgel }} \\
\hline & & & & \multirow{4}{*}{80,50} \\
\hline F4 & 20,15 & 4,5 & 77,32 & \\
\hline \multirow[t]{2}{*}{ F4 } & 20,55 & 7 & 72,74 & \\
\hline & & 5,6 & & \\
\hline F4 & 22,25 & 1,9 & 91,46 & \\
\hline
\end{tabular}

penurunan luka bakar didapatkan bahwa emulgel kitosan-ekstrak kentang 20\% dan kontrol positif memiliki hasil penurunan diameter luka bakar tertinggi. Emulgel kitosan-ekstrak kentang dengan konsentrasi $20 \%$ diduga memiliki efektifitas yang sama denga kontrol positif, ini dikarenakan didalam ekstrak kentang terdapat kandungan kimia berupa flavonoid. Flavonoid termaksud senyawa fenolik yang memiliki gugus fungsi hidroksil sehingga lebih muda masuk ke sel dan membentuk kompleks dengan protein membran sel ,dimana terjadi interaksi dengan melibatkan ikatan hidrogen yang terikat pada bagian hidrofilik membran sel menyebabkan terjadinya peruraian dan

\section{A. Perbandinganpengujian}

Efektivitas Sediaan Emulgel

Kitosan-Ekstrak Kentang dan efektivitas sediaan emulgel ekstrak daun kersen (Muntingia calabura L.)

\begin{tabular}{ccc}
\hline No & Formula & $\begin{array}{c}\text { Rata-rata } \\
\text { Persentase } \\
\text { penyembuhan } \\
\text { luka bakar (\%) }\end{array}$ \\
\hline 1 & $\begin{array}{c}\text { Sediaan Emulgel } \\
\text { Kitosan-Ekstrak } \\
\text { Kentang 10 \% }\end{array}$ \\
\hline 2 & $\begin{array}{c}\text { Sediaan Emulgel } \\
\text { Kitosan-Ekstrak } \\
\text { Kentang 20\% }\end{array}$ \\
\hline
\end{tabular}

Ket $: \mathrm{K}+$ : kontrol positif

K- $\quad:$ Kontrol negatif

F : Formula

d1 : Rata-rata diameter

luka bakar hari ke-1

d23 : Rata-rata diameter

luka bakar hari ke-23

P\% : Persentase

Penyembuhan Luka bakar

kemudian diikuti penetrasi senyawa fenolik ke dalam sel yang selanjutnya mengalami denaturasi protein membran sel sehingga membran sel rusak dikarenakan perubahan permeabilitas sehingga lisisnya membran sel bakteri. Selain sebagai antibakteri, flavonoid juga berperan sebagai antioksidan dengan mekanisme kerja menangkal radikal bebas saat proses penyembuhan luka dan aktivitas antioksidan membantu dalam penyembuhan luka karena saat penyembuhan luka fibriblast berproliferasi dan memproduksi matriks kolagen untuk memperbaiki jaringan yang rusak, produksi matriks kolagen dapat menurun karena peningkatan radikal bebas sehingga diperluakan adanya antioksidan sebagai penetrasi radikal bebas.

\begin{tabular}{ccc}
\hline 3 & $\begin{array}{c}\text { efektivitas sediaan } \\
\text { emulgel ekstrak } \\
\text { daun kersen 10\% }\end{array}$ & 68,38 \\
\hline 4 & efektivitas sediaan & 79,37 \\
& emulgel ekstrak & \\
& daun kersen 20\% & \\
\hline
\end{tabular}


Dari hasil diatas rata-rata persentase penyumbuhan luka bakar untuk sediaan Emulgel Kitosan-Ekstrak Kentang $10 \%$ adalah $69,15 \%$, Sediaan Emulgel Kitosan-Ekstrak Kentang 20\% adalah 80,50\%, efektivitas sediaan emulgel ekstrak daun kersen $10 \%$ adalah 68,38, efektivitas sediaan emulgel ekstrak daun kersen 10\% adalah 79,37

\section{Kesimpulan}

Berdasarkan hasil penelitian dari pengaruh pemberian sediaan emulgel kitosan-

ekstrakkentang(SolanumtuberosumL.) terhadappenyembuhanlukabakar pada kelinci dapat disimpulkan sebagai berikut:

1. Sediaan emulgel-kitosan ekstrak kentang dan Sediaan emulgel ekstrak daun kersen (Muntingia calabura L.) dengan kitosan sebagai gelling agent efektif dalam proses penyembuhan luka bakar dilihat dari pengecilan diameter luas lukabakar.

2. Perbandingan efektifitas penyembuhan antara sediaan emulgel-kitosan ekstrak kentang dan sediaan emulgel ekstrak daun kersen (Muntingia calabura L.) dapat dilihat dari diameter penyembuhan dan paling besar dalam penyembuhannya adalah sediaan emulgel-kitosan ekstrak kentang $20 \%$ yaitu $80,50 \%$.

\section{Daftar pustaka}

Abdurahmat. A., 2014. Luka, Peradangan dan

Pemulihan. Jurnal Entropi. Vol. 9. No. 1. Hlm. 721840. ISSN. 1907-1965.

Amaliah. R., 2017. Hasil Belajar Biologi Materi Sistem Gerak Dengan Menerapkan Model
Pembelajaran Kooperatif

Tipe Rotating Trio Exchange (RTE) Pada Siswa Kelas XI SMAN 4

Bantimurung. Jurnal Dinamika. Vol. 8. No.1. Hlm. 11-17. P-ISSN : 2087-889. E-ISSN: 25034863.

Angel L, 2012. Aktivitas Antioksidan dan Stabilitas Fisik Gel Anti-Aging yang Mengandung Ekstrak Air Kentang Kuning (Solanum tuberosum

L.).Skripsi.Fakultas

Matematika dan Ilmu Pengetahuan Alam Studi Farmsi Depok.

Balqis.U.,dkk.2016.EfikasiMentimun( CucumissativusL.)Terhad apPercepatan

PenyembuhanLukaBakar( Vulnuscombustion)Deraja tIIBPadaTikus Putih (Rattus norvegicus). Jurnal Medika Veterinaria. Vol. 10.No.2.

Dewi, Rismala. 2014. Tata Laksana Luka Bakar Pada Anak.Current Evidences in Pediatric Emergencies Management. Pendidikan Kedokteran Berkelanjutan LXVIII. Fakultas Kedokteran Universitas Indonesia.

Dzulfikar. 2012. Penanganan Luka Bakar Di Ruang Perawat Intensif Anak.MajalahKedokteran Terapi Intensif. Vol. 2,No. 